\title{
INTERRELATIONSHIPS AMONG THE CHARACTERISTICS OF GUINEA-PIG SEMEN COLLECTED BY ELECTRO-EJACULATION
}

\author{
MATTHEW FREUND \\ Laboratory of Reproductive Pharmacology, Departments of Pharmacology \\ and of Obstetrics and Gynecology, New York Medical College, \\ Flower and Fifth Avenue Hospitals, New York, U.S.A.
}

(Received 24th Fune 1968, accepted 8th Fanuary 1969)

\begin{abstract}
Summary. Methods and equipment for collection of guinea-pig semen by electro-ejaculation and for liquefaction of coagulated semen ('rodent vaginal plug') with chymotrypsin are described. The electro-ejaculator was designed to deliver a 1000-cycle 12-volt square wave, via ano-lumbar ( $\mathrm{L} 1$ to L4) pathways, with an automatic 3-sec 'on period' and 12sec 'off period'. Thirty semen specimens were collected at weekly intervals from each of twenty-nine unselected guinea-pigs. Means for semen characteristics of the 870 specimens were: sperm concentration per ejaculate, $13.376 \times 10^{6}$; ejaculate volume, $0.5 \mathrm{ml}$; percentage motility, $66 \%$; percentage normal morphology, 95\%. Mean fructose concentration was $102 \mathrm{mg} \%$. Oxygen uptake by the spermatozoa was large and the $\mathrm{ZO}_{2}\left(\mu \mathrm{l} / 10^{8}\right.$ spermatozoa $\left./ \mathrm{hr}\right)$ was calculated to be $25 \cdot 03$. Stimulation of vertebral levels L1 to L4 simultaneously resulted in ejaculation without erection while stimulation of any one of levels L5, L6, S1, S2 resulted in erection. The method described appears to be a precise, repeatable and non-traumatic method of electro-ejaculation which is useful in studies to determine the effects of radiation or drugs on sperm production in the guinea-pig.
\end{abstract}

\section{INTRODUCTION}

The method for electro-ejaculation of guinea-pigs at the time that this work was started was the technique of Batell (1922), as modified by Moore \& Gallagher (1930), Sayles (1939) and Durfee, Lerner \& Kaplan (1940). Three 10 -sec shocks of 5 to 35 volts AC were applied, using a blunt electrode in the mouth and a needle electrode at the base of the skull. Ejaculation usually followed violent and spasmodic whole-body responses. When this method was applied in our laboratory, it was severely traumatic to guinea-pigs; cessation of breathing, massive tonic contraction and eversion of anal mucosa were noted. Furthermore, ejaculation did not uniformly occur and it was often necessary to repeat the stimuli several times. The ejaculate was coagulated, with no liquid fraction, and did not liquefy after several hours at room tempera- 
ture. Finally, the use of 35 volts of 60 -cycle $\mathrm{AC}$ was dangerous both to animal and operator. Oriol-Bosch \& Parada (1960), using similar methods, found the same side-effects and reported 116 ejaculations in 148 collections $(72 \%)$.

An attempt was, therefore, made to develop a more precise and less traumatic method of electro-ejaculation and a practical technique for liquefaction of the semen coagulum. Dalziel \& Phillips (1948) reported a technique for electroejaculation of chinchillas and guinea-pigs using ano-lumbar pathways, but did not analyse the semen collected. They found that use of 1000-cycle instead of 60-cycle AC abolished side-effects and that a square-wave stimulus gave a more uniform ejaculatory response. An apparatus was built in this laboratory to deliver a 1000 -cycle square wave at 0 to 25 volts root mean square (rms) with a timer to give a 3-sec 'on period' and 12-sec 'off period'. The preliminary use of this instrument was described (Freund, 1958) and studies of factors affecting guinea-pig semen production using the technique have been reported (Freund, 1962a; Freund \& Borrelli, 1964a, b; Freund \& Borrelli, 1965). The successful application of this technique to collect guinea-pig semen for a study of sperm-size distribution has been reported (Laurence \& Carpuk, 1963).

This report includes a description of technique and apparatus, data on the characteristics and metabolism of guinea-pig semen and an analysis of spinal levels involved in erection and ejaculation.

\section{Apparatus}

\section{MATERIALS AND METHODS}

The electro-ejaculator was made up of a signal source (Heath Voltage Calibrator, Model VC-3), 12-watt amplifier (Eico, Model HF-12), 0 to 25 volt voltmeter, 0 to $25 \mathrm{~mA}$ ammeter, and switches and pilot lights. The signal source produced a 1000-cycle square wave which was the input to the amplifier. Application of the stimulus was controlled by a timer consisting of a constant speed motor which drove a cam at one rotation per $15 \mathrm{sec}$. One fifth of the cam was cut off so that as the cut-off part passed a microswitch it completed the circuit for 3 out of every $15 \mathrm{sec}$, yielding an automatic 3 -sec 'on period' and 12-sec 'off period'. These sections of the apparatus are shown in Plate 1(b). The ammeter and voltmeter were provided to warn of malfunction and to protect the animal. The entire apparatus was grounded through the 3-wire line cord and plug. The apparatus was provided with a line switch and pilot light and a timer switch and pilot light. These sections of the apparatus are shown in Plate $\mathrm{I}(\mathrm{a})$. In 10 years of use, this technique has never resulted in electrocution of an animal. In order to facilitate calibration, resistance measurements were made on twenty guinea-pigs and a guinea-pig analogue, representing the mean resistance, was constructed (Text-fig. 1). For calibration, the output of the electro-ejaculator was connected to the analogue, the wave form was displayed on an oscilloscope, and the controls on the amplifier were set to yield a 12-volt square wave. Although in our preliminary work (Freund, 1958) 24 volts rms were used, it was soon found that the voltage could be reduced as far as 12 volts rms without loss of ejaculatory response. Below 12 volts, however, ejaculatory response became erratic and unpredictable. 

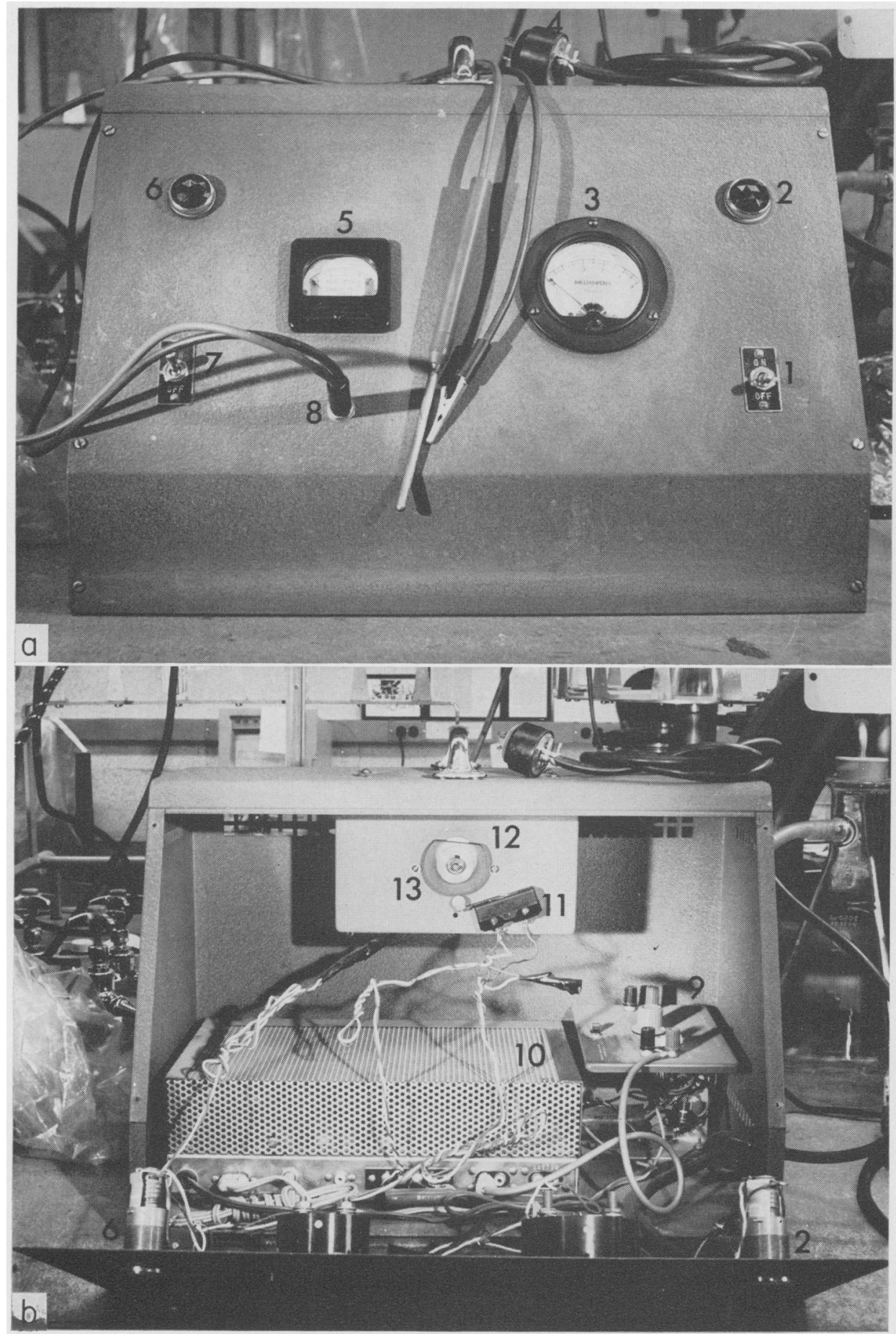

Exterior hat and interior (b) of electro-ejaculator: 1. line switch: 2. line pilot light:

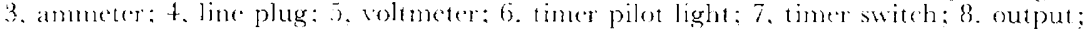

9. signal souret: 10, amplifier: 11. microswiteh: 12, comstant speed noolor: 13. (an). 
PI,ATE, 2

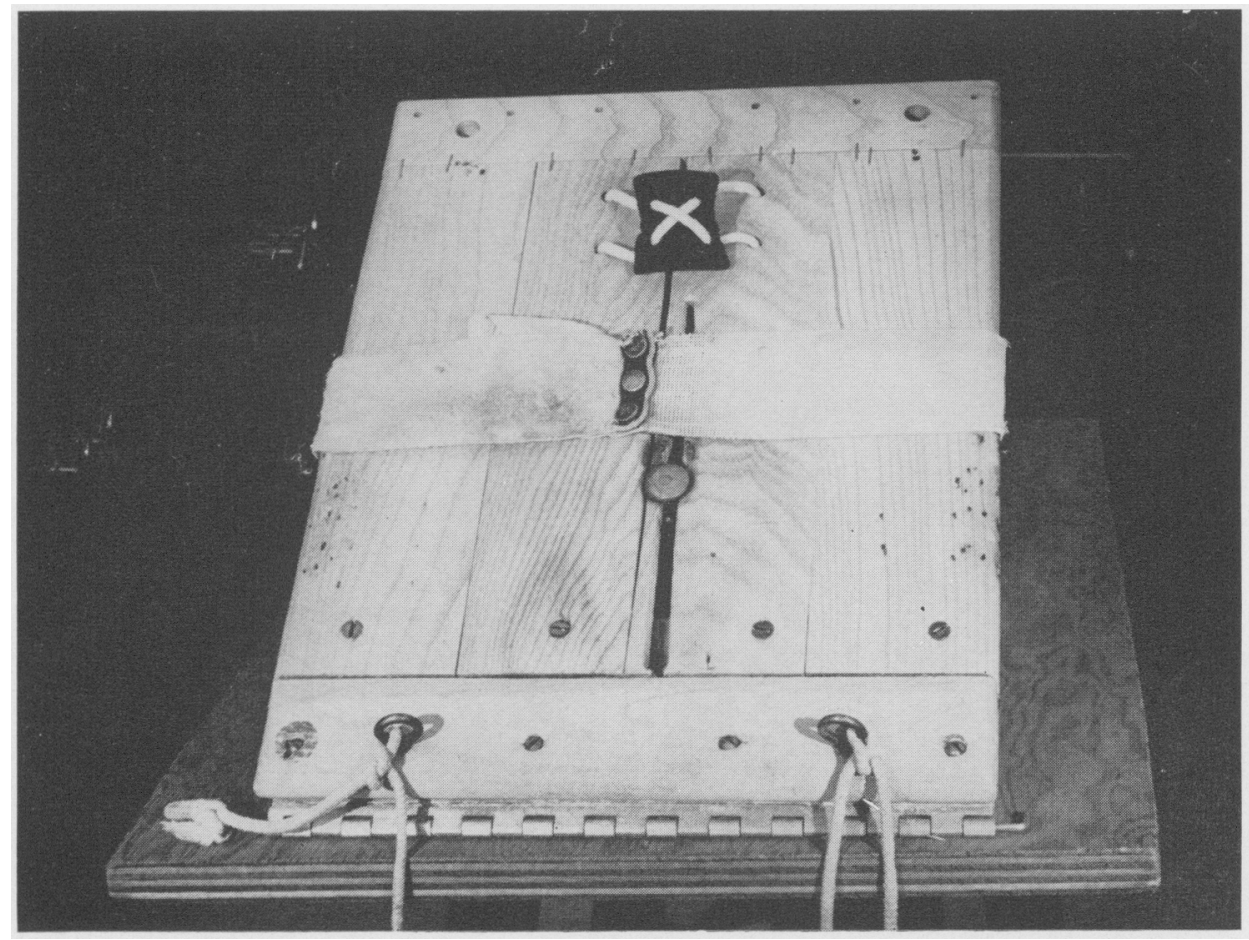

Animal board. The lumbar electrode is a copper disc with a screw back which can be moved up and down in the slot on the animal board as required by the size of the animal. 
Animals

Guinea-pigs of the English strain (Rockland Farms) were obtained at 4 to 6 weeks of age ( 250 to $300 \mathrm{~g}$ ) and raised to maturity $(800 \mathrm{~g})$ in individual cages on wire grilles. They were maintained on a ration with added vitamin $\mathrm{C}$, daily greens, and tap water. After the animals reached maturity, semen was collected by electro-ejaculation at weekly intervals. Since these were large guinea-pigs ( 800 to $1300 \mathrm{~g}$ ), an animal board (Plate 2) was mounted at a $45^{\circ}$ angle so that the animal could be tied down on its back and yet permit the flow of semen into the collecting graduate. The board had a slot in it so that the lumbar electrode, a copper disc of $1.75 \mathrm{~cm}$ diameter, could be moved up
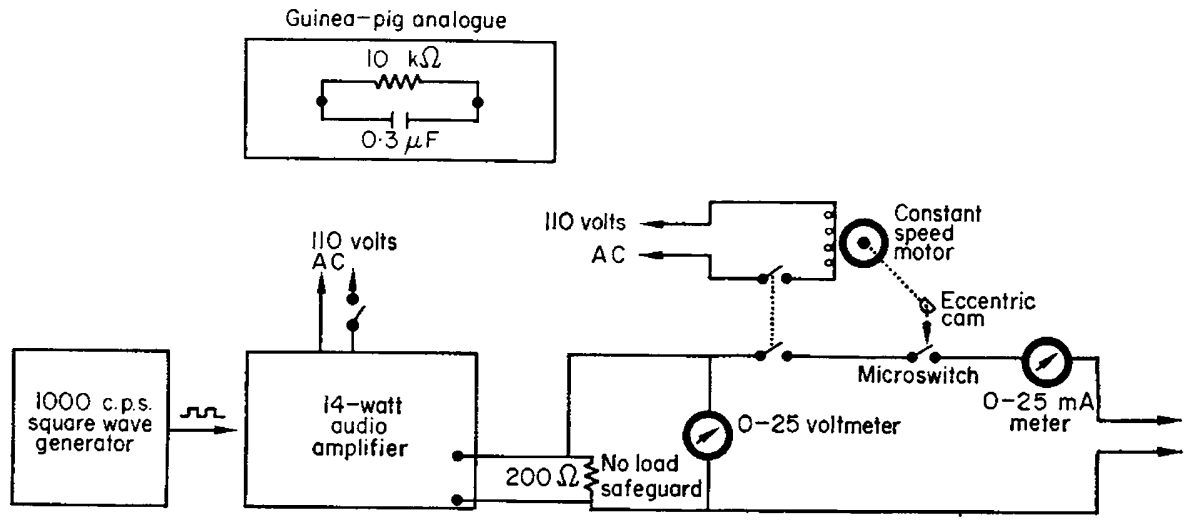

TEXT-FIG. 1. Block diagram of electro-ejaculator and of guinea-pig analogue.

and down as required by the size of the animal (Plate 2). The electrical connection to the lumbar electrode was an alligator clip (Plate 1a). The anal electrode (length $\cong 8.0 \mathrm{~cm}$, diameter $\cong 0.4 \mathrm{~cm}$ ) was a smooth brass tube (Plate la). The animal was restrained by a leather chest holder (Plate 2) because articulation of the fore legs is such that tying the legs up and back may result in permanent damage. The hind legs were tied with cord and an elastic strap was used to keep the animal pressed against the lumbar electrode.

\section{Collection of semen}

The hair was clipped from the lumbar and sacral region and electrode jelly was applied to the skin to ensure electrical contact with the lumbar electrode. The guinea-pig was strapped to the board and its hind legs were tied. The lumbar electrode was positioned at L2 to L3. The anal electrode was dipped in lubricating jelly and inserted 4 to $6 \mathrm{~cm}$ into the rectum. A series of five 3-sec stimuli was then given, using the timer to give 3-sec 'on periods' and 12-sec 'off periods'. Semen was usually ejaculated during the first or second 'on period' and continued to flow during the successive periods of stimulation. The semen was collected into $1 \mathrm{ml}$ of chymotrypsin-phosphate solution $(1 \mathrm{mg}$ chymotrypsin/ml phosphate solution) in order to liquefy the semen coagulum which formed almost instantaneously upon ejaculation (Freund, 1958). Semen characteristics were determined by methods which are standard in this 
laboratory (Freund, 1962b) : ejaculate volume by collection into a 5 -ml graduated cylinder, sperm concentration by counting in a haemocytometer, motility by rating to the nearest $10 \%$ under low power on a warm stage at $39^{\circ} \mathrm{C}$, and morphology by counting after fixation and staining. The data were calculated as semen volume in $\mathrm{ml} /$ ejaculate; sperm concentration $\times 10^{6} / \mathrm{ml}$; sperm concentration $\times 10^{6} /$ ejaculate; sperm motility in percentage motility; sperm morphology in percentage normal forms; and motile sperm $\times 10^{6} /$ ejaculate.

Fructose determinations were made by a modification of the method of Roe, as described by Freund, Mixner \& Mather (1957). Sperm respiration was measured for $3 \mathrm{hr}$ at $37^{\circ} \mathrm{C}$ by the direct method of Warburg (Umbreit, Burris \& Stauffer, 1964). Three-ml aliquots of semen were pipetted into 15-ml flasks; the gas phase was air, and penicillin was added to inhibit bacterial activity. Three semen flasks and three sperm-free seminal plasma flasks were run in each of four trials. Percentage motility was rated at the beginning and end of each trial.

\section{RESULTS}

\section{Characteristics of guinea-pig semen}

Thirty specimens were collected at weekly intervals from twenty-nine unselected guinea-pigs in order to determine interrelationships among semen characteristics and to compare variability in semen characteristics among repeated ejaculates from the same animal and among the means for semen characteristics among animals. The means for the semen characteristics of the 870 specimens are presented in Table 1 . For the sake of brevity, only the means for the four guinea-pigs with the highest (Nos. 1 to 4), the four with the lowest (Nos. 26 to 29), and the four with the median sperm concentrations per ejaculate are included. Wide variations in semen characteristics, particularly sperm concentration and specimen volume, are evident (Table 1). Means for sperm concentration per ejaculate in this study ranged from $2.875 \times 10^{6}$ to $35.003 \times 10^{6}$ and the average was $13.376 \times 10^{6}$. This variability in a group of unselected guinea-pigs confirms previous work with groups of unselected men (Freund, 1962b) and bulls (Freund \& Murphree, 1960). However, mean normal morphology was $95 \%$ for the 870 specimens and the lowest mean value was $92 \%$. This contrasts sharply with the wide variation in mean morphologies reported for unselected human donors (Freund, 1962b) and supports the histological impression that spermatogenesis in the rodent is a more precise and wellordered process than in man.

An analysis of variance (Table 2) indicates significant 'among-animal' differences in semen characteristics; that is, more variation among the means for semen characteristics of ejaculates from different guinea-pigs than in semen characteristics among repeated ejaculates from the same guinea-pig. These data provide an experimental and statistical basis for the use of electroejaculation to collect repeated specimens in order to assess the fertility status of a guinea-pig. The apparent exception was motility where a significant difference among animals was not demonstrated (Table 2). In the case of motility, there was not much variability among mean values for animals 
TABLE 1

MEANS OF SEMEN GHARACTERISTICS (870 EJAGULATES)

\begin{tabular}{|c|c|c|c|c|c|c|c|}
\hline $\begin{array}{c}\text { Animal } \\
\text { No. }\end{array}$ & $\begin{array}{c}\text { Sperm } \\
\text { conc. } \\
\left(10^{6} / \mathrm{ml}\right)\end{array}$ & $\begin{array}{c}\text { Ejaculate } \\
\text { volume } \\
(\mathrm{ml})\end{array}$ & $\begin{array}{c}\text { Sperm } \\
\text { conc. } \\
\left(10^{6} / \text { jaculate }\right)\end{array}$ & $\underset{(\%)}{\text { Motility }}$ & $\begin{array}{c}\text { No. of } \\
\text { motile sperm. } \\
\left(10^{6} / \text { ejaculate }\right)\end{array}$ & $\begin{array}{c}\text { Normal } \\
\text { morphology } \\
(\%)\end{array}$ & $\begin{array}{c}\text { Body } \\
\text { weight } \\
(g)\end{array}$ \\
\hline $\begin{array}{l}1 \\
2 \\
3 \\
4\end{array}$ & $\begin{array}{r}51 \cdot 323 \\
110 \cdot 371 \\
97 \cdot 863 \\
67 \cdot 703\end{array}$ & $\begin{array}{l}1 \cdot 0 \\
0 \cdot 3 \\
0 \cdot 2 \\
0.3\end{array}$ & $\begin{array}{l}35 \cdot 003 \\
29 \cdot 000 \\
18 \cdot 409 \\
17 \cdot 570\end{array}$ & $\begin{array}{l}71 \\
67 \\
52 \\
60\end{array}$ & $\begin{array}{r}25 \cdot 099 \\
22 \cdot 154 \\
9 \cdot 346 \\
11 \cdot 742\end{array}$ & $\begin{array}{l}94 \\
98 \\
94 \\
96\end{array}$ & $\begin{array}{l}956 \\
802 \\
932 \\
731\end{array}$ \\
\hline $\begin{array}{l}13 \\
14 \\
15 \\
16\end{array}$ & $\begin{array}{l}25 \cdot 587 \\
37 \cdot 687 \\
25 \cdot 291 \\
21 \cdot 344\end{array}$ & $\begin{array}{l}0.6 \\
0.5 \\
0.5 \\
0.7\end{array}$ & $\begin{array}{l}11.472 \\
11.470 \\
11.249 \\
10.570\end{array}$ & $\begin{array}{l}71 \\
68 \\
74 \\
67\end{array}$ & $\begin{array}{l}8 \cdot 426 \\
7 \cdot 878 \\
8 \cdot 505 \\
7 \cdot 532\end{array}$ & $\begin{array}{l}96 \\
95 \\
96 \\
93\end{array}$ & $\begin{array}{r}951 \\
756 \\
870 \\
1212\end{array}$ \\
\hline $\begin{array}{l}26 \\
27 \\
28 \\
29\end{array}$ & $\begin{array}{l}14 \cdot 271 \\
28 \cdot 010 \\
10 \cdot 753 \\
13 \cdot 181\end{array}$ & $\begin{array}{l}0.6 \\
0.3 \\
0.3 \\
0.6\end{array}$ & $\begin{array}{l}5 \cdot 448 \\
4 \cdot 426 \\
3.023 \\
2 \cdot 875\end{array}$ & $\begin{array}{l}70 \\
59 \\
72 \\
59\end{array}$ & $\begin{array}{l}3.949 \\
2 \cdot 612 \\
2 \cdot 192 \\
1.775\end{array}$ & $\begin{array}{l}92 \\
96 \\
97 \\
97\end{array}$ & $\begin{array}{l}858 \\
686 \\
885 \\
864\end{array}$ \\
\hline $\begin{array}{l}\text { Mean* } \\
\text { values }\end{array}$ & $41 \cdot 782$ & 0.5 & $13 \cdot 376$ & 66 & $9 \cdot 268$ & 95 & 875 \\
\hline
\end{tabular}

* Means for all twenty-nine animals in the study.

TABLE 2

ANALYSIS OF VARIANGE OF SEMEN CHARAGTERISTICS

\begin{tabular}{|c|c|c|c|}
\hline Semen characteristics & Source of variation & d.f. & Mean square \\
\hline Sperm concentration $\left(10^{6} / \mathrm{ml}\right)$ & $\begin{array}{l}\text { Among animals } \\
\text { Ejaculates within animals } \\
\text { Total }\end{array}$ & $\begin{array}{r}28 \\
841 \\
869\end{array}$ & $\begin{array}{c}16,422^{*} \\
1541\end{array}$ \\
\hline Ejaculate volume & $\begin{array}{l}\text { Among animals } \\
\text { Ejaculates within animals } \\
\text { Total }\end{array}$ & $\begin{array}{r}28 \\
841 \\
869\end{array}$ & $\begin{array}{l}85 \cdot 8571^{*} \\
12 \cdot 6266\end{array}$ \\
\hline Sperm concentration ( $\times 10^{6} /$ ejaculate) & $\begin{array}{l}\text { Among animals } \\
\text { Ejaculates within animals } \\
\text { Total }\end{array}$ & $\begin{array}{r}28 \\
841 \\
869\end{array}$ & $\begin{array}{c}1471^{*} \\
137\end{array}$ \\
\hline Motility & $\begin{array}{l}\text { Among animals } \\
\text { Ejaculates within animals } \\
\text { Total }\end{array}$ & $\begin{array}{r}28 \\
841 \\
869\end{array}$ & $\begin{array}{l}125 \\
264\end{array}$ \\
\hline No. motile spermatozoa $\left(\times 10^{6} /\right.$ ejaculate $)$ & $\begin{array}{l}\text { Among animals } \\
\text { Ejaculates within animals } \\
\text { Total }\end{array}$ & $\begin{array}{r}28 \\
841 \\
869\end{array}$ & $\begin{array}{l}789 * \\
84\end{array}$ \\
\hline Normal morphology & $\begin{array}{l}\text { Among animals } \\
\text { Ejaculates within animals } \\
\text { Total }\end{array}$ & $\begin{array}{r}28 \\
841 \\
869\end{array}$ & $\begin{array}{c}117^{*} \\
23\end{array}$ \\
\hline Body weight & $\begin{array}{l}\text { Among animals } \\
\text { Ejaculates within animals } \\
\text { Total }\end{array}$ & $\begin{array}{r}28 \\
841 \\
869\end{array}$ & $\begin{array}{c}490,050^{*} \\
6445\end{array}$ \\
\hline
\end{tabular}

* Statistically significant $(P<0.01)$.

(Table 1) while the raw data indicate great variability among motility ratings made on repeated specimens from the same animal. This anomalous distribution of the variance may have been due to the unusual type of motility found in guinea-pig semen, which was previously described (Freund, 1958), and the 
resulting difficulties in making accurate estimates of percentage motility. The swimming patterns of guinea-pig spermatozoa are curvilinear and characterized by irregular forward progression, as compared to bull or human spermatozoa. Furthermore, the frequent formation of 'head-to-head' rouleaux, as previously described (Freund, 1958), makes motility rating difficult.

Further examination of the interrelationships among semen characteristics may be made by correlation analysis (Table 3 ). Sperm concentration $/ \mathrm{ml}$ was negatively correlated with volume on total and ejaculates-within-animal bases while sperm concentration/ejaculate was positively correlated with volume on total, among-animals, and ejaculates-within-animal bases (Table 3).

TABLE 3

CORRELATIONS AMONG VARIOUS SEMEN CHARACTERISTICS

\begin{tabular}{|c|c|c|c|}
\hline \multirow[b]{2}{*}{ Correlated factors and d.f. } & \multicolumn{3}{|c|}{ Coefficients of correlation and d.f. } \\
\hline & Total & $\begin{array}{l}\text { Among } \\
\text { animals }\end{array}$ & $\begin{array}{l}\text { Ejaculates } \\
\text { within } \\
\text { animals }\end{array}$ \\
\hline $\begin{array}{l}\text { Sperm concentration per ml semen and: } \\
\text { Ejaculate volume } \\
\text { Motility }(\%) \\
\text { Normal morphology }(\%) \\
\text { Body weight }\end{array}$ & $\begin{array}{l}-0.29 \dagger \\
-0.12 \dagger \\
-0.01 \\
-0.08 *\end{array}$ & $\begin{array}{r}-0.35 \\
-0.26 \\
0.07 \\
-0.23\end{array}$ & $\begin{array}{l}-0.28 \dagger \\
-0.09 \dagger \\
-0.02 \\
0.05\end{array}$ \\
\hline $\begin{array}{l}\text { Sperm concentration per ejaculate and: } \\
\text { Ejaculate volume } \\
\text { Motility }(\%) \\
\text { Normal morphology }(\%) \\
\text { Body weight }\end{array}$ & $\begin{array}{c}0.30 \dagger \\
0.13 \dagger \\
-0.02 \\
0.10 \dagger\end{array}$ & $\begin{array}{c}0.40^{*} \\
0.02 \\
-0.01 \\
0.03\end{array}$ & $\begin{array}{l}0.29 \dagger \\
0.16 \dagger \\
-0.02 \\
0.19 \dagger\end{array}$ \\
\hline $\begin{array}{l}\text { Ejaculate volume and: } \\
\text { Motility }(\%) \\
\text { No. of motile sperm. per ejaculate } \\
\text { Body weight }\end{array}$ & $\begin{array}{l}0.23 \dagger \\
0.33 \dagger \\
0.27 \dagger\end{array}$ & $\begin{array}{l}0 \cdot 29 \\
0 \cdot 37^{*} \\
0 \cdot 41^{*}\end{array}$ & $\begin{array}{l}0 \cdot 22 \dagger \\
0 \cdot 29 \dagger \\
0.26 \dagger\end{array}$ \\
\hline $\begin{array}{l}\text { Motility }(\%) \text { and: } \\
\text { No. of motile sperm. per ejaculate } \\
\text { Normal morphology }(\%)\end{array}$ & $\begin{array}{l}0.31 \dagger \\
0.14 \dagger\end{array}$ & $\begin{array}{l}0.17 \\
0.27\end{array}$ & $\begin{array}{l}0.35 \dagger \\
0.12 \dagger\end{array}$ \\
\hline $\begin{array}{l}\text { No. of motile sperm. per ejaculate and: } \\
\text { Normal morphology }(\%) \\
\text { Body weight }\end{array}$ & $\begin{array}{l}0.01 \\
0.11 \dagger\end{array}$ & $\begin{array}{l}0.03 \\
0.03\end{array}$ & $\begin{array}{l}0.00 \\
0.21 \dagger\end{array}$ \\
\hline d.f. & 868 & 27 & 840 \\
\hline
\end{tabular}

* Statistically significant $(P<0.05)$.

+ Statistically significant $(P<0.01)$.

This suggests that when a large volume of semen was ejaculated, although the sperm concentration/ml declined, the total number of spermatozoa increased. This was as expected since the seminal plasma dilutes the spermatozoa at ejaculation. The increase in the total number of spermatozoa was evident among successive ejaculates from the same animal. In man, the tendency of semen characteristics in a specimen to be either all high or all low, that is, to be significantly correlated, reflects the influence of the donor, since this correlation does not exist on a specimens-within-donor basis, that is, among repeated specimens from the same donor (Freund, 1962b). In the guinea-pig, the correlation 
exists on total, among-animals, and ejaculates-within-animal bases, which may indicate an effect of electro-ejaculation resulting in a larger specimen, containing more spermatozoa, with some animals being more amenable to complete ejaculation as the result of electrical stimulation. Sperm morphology was apparently not highly correlated (Table 3 ) with the other semen characteristics which may be a reflection of the uniformity of guinea-pig spermatozoa (Table 1) and the lack of variability in percentage normal morphology among animals and among repeated specimens from the same animal.

A record was made of the relative degree of coagulation or liquefaction of each ejaculate before the semen was mixed with the chymotrypsin-phosphate diluter. The semen was rated visually as coagulated or liquefied on a scale that ranged from ++++ coagulated/0 liquefied (completely coagulated), through ++ coagulated $/++$ liquefied $(50 \%$ coagulated and $50 \%$ liquefied $)$, to 0 coagulated $/++++$ liquefied (completely liquefied). At the first collection, among the twenty-nine animals, six specimens were ++++ coagulated $/ 0$ liquefied, twenty-two were +++ coagulated $/+$ liquefied, and only one was + coagulated $/+++$ liquefied. However, 10 weeks later, only two specimens were still ++++ coagulated/0 liquefied and six were +++ coagulated $/+$ liquefied, while nine were ++ coagulated $/++$ liquefied, three were + coagulated $/+++$ liquefied, and nine were 0 coagulated $/++++$ liquefied. At the end of the 30-week period of regular collection, all of the animals were delivering liquid semen that contained only small and scattered islands of coagulum.

\section{Metabolism of guinea-pig semen}

Assay for fructose was made on 208 specimens, thirteen ejaculates from each of sixteen animals. Mean fructose concentration was $102 \mathrm{mg} \%$ (range of animal means $=54 \mathrm{mg} \%$ to $152 \mathrm{mg} \%$ ). This compares quite closely to the $100.8 \mathrm{mg} \%$ reported by Oriol-Bosch \& Parada (1960) for the fructose concentration of the liquid fraction of coagulated guinea-pig semen, collected by the method of Sayles (1939). In sperm respiration studies, pooled semen was used and mean sperm concentration was $9.538 \times 10^{6} / \mathrm{ml}$, mean initial motility $60 \%$, and final motility $45 \%$. Oxygen uptake by sperm-free seminal plasma was small and averaged $0.78 \mu \mathrm{l} / \mathrm{hr}$. Oxygen uptake by spermatozoa (mean of $28.612 \times 10^{6} \mathrm{cells} /$ flask) was large and, corrected for plasma uptake, was $7 \cdot 16 \mu \mathrm{l} / \mathrm{hr} /$ flask. The $\mathrm{ZO}_{2}\left(\mu \mathrm{l} / 10^{8}\right.$ spermatozoa/hr) was calculated to be $25 \cdot 03$.

\section{Erection and ejaculation in the guinea-pig}

In routine electro-ejaculation, the lumbar electrode was a copper disc of $1.75 \mathrm{~cm}$ diameter placed at L2 to L3 and electrode jelly was applied to be certain of delivering an adequate stimulus to vertebral levels L1 to L4. Ejaculation invariably followed stimulation. Erection was noted only when the electrode was moved down into the sacral area.

In order to determine the vertebral levels at which erection and ejaculation occur, under the conditions of this study, a bar electrode $(2.5 \times 0.5 \mathrm{~cm})$ and a clip electrode (alligator electrical clip) were substituted for the round electrode in separate trials, in which no electrode jelly was used and the anal electrode and all electrical parameters of stimulation were kept constant. The bar 
electrode was more useful than the clip in inducing erection and in localizing the vertebral level stimulated. The clip was attached solely to the skin and the guinea-pig can move its body inside the skin so that the vertebral-skin apposition is changed. By contrast, the animal was held against the bar electrode by the elastic strap (Pl. 2), and by the pressure of the operator's left hand on its abdomen as he extruded the penis with the fingers of his left hand. Using the bar electrode, four or more trials were made at each of levels Ll to Gl on different animals. No erection was observed at levels L1 to L4 (0/19 trials); consistent erection at levels L5, L6, and S1, S2 (11/12); and inconsistent erection at $\mathrm{S} 3$ and $\mathrm{C} 1$ (4/8). Ejaculation was found at L1 to L3 (14/48 trials); not at L4 to L6 $(2 / 23)$ or at S1 to S3 (1/24); and again at C1 (3/4). In view of the low incidence of ejaculation after stimulation of a single vertebral level, two levels were stimulated simultaneously. Low incidence of ejaculation was observed after stimulation of L1 and L2, L2 and L3, L3 and L4, L4 and L5, L5 and L6, L6 and S1, S1 and S2 (4/28 trials); higher incidence of ejaculation after stimulation of $\mathrm{L} 1$ and $\mathrm{S} 1, \mathrm{~L} 2$ and $\mathrm{S} 1, \mathrm{~L} 3$ and $\mathrm{S} 1, \mathrm{~L} 4$ and $\mathrm{S} 1$ (12/18); and a low incidence after L1 and S2, L2 and S2, L3 and S2 (3/17). The most effective combinations of two levels were L2 and S1 (4/4 trials), L3 and S1 (4/7), and L4 and $\mathrm{S} 1(2 / 3)$.

\section{DISCUSSION}

A major problem in electro-ejaculation at regular intervals, for example once a week, is the determination of when a complete specimen has been collected. When semen is collected in the artificial vagina, it is assumed that complete ejaculation has taken place. With electro-ejaculation it is possible to collect very large amounts of semen by electro-ejaculation to exhaustion. When electroejaculation is used with the bull, it is applied until a predetermined volume of semen is collected and this is called the 'ejaculate'. In a study on the effects of irradiation on semen production in Hereford bulls (Freund \& Murphree, 1960), two consecutive specimens of $5 \mathrm{ml}$ each were collected three times a week, for a total of six specimens per bull per week. This volume was chosen because it approximated to the mean value reported for bull ejaculates collected in the artificial vagina. In the guinea-pig, however, the volume of semen ejaculated at coitus is not known and ejaculates have not been collected in an artificial vagina to determine volume. Furthermore, because of the semen coagulum and the necessity for restraining the animal, it is impractical to monitor semen volume during collection. Therefore, a regular number of stimuli (five) were applied to standardize the procedure rather than continuing until 'enough' of a specimen had been collected. This approach has been confirmed by the data (Tables 1 and 2) which showed that ejaculates produced at once a week intervals by electro-ejaculation with five stimuli were different and characteristic for each animal in the group, in terms of specimen volume and sperm concentration.

It is difficult to compare the data in this study with the report of Scott \& Dziuk (1959) on use of a bipolar rectal electrode for collection of guinea-pig semen. Their report does not detail the number of animals that were regularly 
collected, the number of specimens per animal, the total number of specimens collected, the method of selection of animals which were to be collected and/or of specimens which were to be counted, or the actual technique used to determine ejaculate volume or sperm concentration. No tables of data or statistical analyses are presented.

Strain differences in semen characteristics may be a complicating factor in the comparison of data reported by different investigators. In this laboratory, the twenty-nine guinea-pigs used in this study from one breeder (Rockland Farms) produced a mean specimen volume of $0.5 \mathrm{ml}$ with a range from 0.2 to $1.0 \mathrm{ml}$ ( 870 specimens), while a similar group of thirty-nine animals supplied by another breeder (Laboratory Animals) produced a mean volume of $1.5 \mathrm{ml}$ with a range from 0.4 to $2.2 \mathrm{ml}$ (468 specimens). On the other hand, the first group produced a mean of $13.376 \times 10^{6}$ spermatozoa per ejaculate with a range from 2.875 to $35.003 \times 10^{6}$, while the second group produced a mean of $8.033 \times$ $10^{6}$ spermatozoa/ejaculate with a range from 0.484 to $31.879 \times 10^{6}$. Thus, although there was marked difference (3 times) in semen volume among strains, the sperm output was more comparable ( 1.7 times).

In a preliminary report on guinea-pig semen (Freund, 1958), it was pointed out that there was a trend, over several months of electro-ejaculation, for ejaculated semen to remain liquid and fail to clot. This was true even though collections were made at bi-weekly intervals. In this study, where the animals were collected at weekly intervals, the trend toward liquid semen was noted again. By the 6th week of collection, many animals were ejaculating liquid specimens that were either free of coagulum or else contained scattered islands of coagulum visible only under the microscope. Recently, Bennett (1967) demonstrated in the squirrel monkey that, after repeated electro-ejaculation at 5-day intervals, the amount of coagulum decreased and the sperm-rich fluid increased.

It is evident that data on vertebral levels that control erection and ejaculation can not be used to locate these spinal centres precisely in the guinea-pig. When external stimuli are applied, the discrete part of the nervous system that receives the effective stimulus is uncertain, since the spinal root efferents or the spinal cord centres (or both) may have been stimulated. Furthermore, as in the cat (Semans \& Langworthy, 1938), the spinal efferents that play a role in erection and ejaculation run parallel to the cord for variable distances before running out to the periphery. Nevertheless, certain conclusions may be drawn about the application of electro-ejaculation, using ano-lumbar pathways. Erection consistently occurs when any one of levels L5, L6, S1 and S2 is stimulated, which suggests that where ejaculation without erection is desired, stimulation of levels below L4 should be avoided. Although ejaculation did not take place in some cases $(29 \%)$ when only one level from $\mathrm{L} 1$ to $\mathrm{L} 3$ was stimulated, from $\mathrm{L} 4$ to $\mathrm{C} 1$ there was an extremely low incidence of ejaculation $(12 \%)$. However, when any one level from L1 to L4 was stimulated simultaneously with S1, ejaculation (preceded by partial or complete erection) occurred much more frequently $(67 \%)$. This was not the case when any one lumbar level was stimulated simultaneously with S2, since the incidence of ejaculation was much lower $(17 \%)$. These observations support the neurophysiological work of 
Semans \& Langworthy (1938), in the cat, who concluded that emission of seminal fluid into the urethra is mediated by way of lumbar roots and ejaculation of semen from the urethra through sacral roots. In routine work, where Ll to L4 is stimulated with a disc electrode and electrode jelly, there is a regular flow of semen without erection and the author has interpreted this flow as ejaculation since the semen is usually expelled with considerable force and seems to flow only during the 'on period' of the stimulus cycle. However, if the data of Semans \& Langworthy (1938) apply equally well to the guinea-pig, electroejaculation without erection may really be only emission since true ejaculation, or forceful expulsion of semen from the urethra, may be possible only after erection has taken place.

\section{ACKNOWLEDGMENTS}

This investigation was supported by Grant HD-03466-09 from the National Institute of Child Health and Human Development, National Institutes of Health, U.S. Public Health Service. The author gratefully acknowledges the technical assistance of $\mathrm{Mr}$ Joseph Nelson, Dr Philip Taylor and Mr Nelson Breamfield, and wishes to thank Miss Ollie Brown for her clerical assistance in preparation of the manuscript. The author is a Career Scientist of the Health Research Council of the City of New York (I-218).

\section{REFERENCES}

Batelir, F. (1922) Une méthode pour obtenir l'émission complète du liquide des vesicules séminales chez le cobaye. C. r. Séanc. Soc. Phys. Hist. nat. Genève, 39, 73.

BenNetr, J. P. (1967) Semen collection in the squirrel monkey. F. Reprod. Fert. 13, 353.

Dalzies, C. F. \& Phillips, C. L. (1948) Electric ejaculation. Determination of optimum electric shock to produce ejaculation in chinchillas and guinea pigs. Am. F. vet. Res. 9, 225.

Durfee, T., Lerner, M. W. \& Kaplan, N. (1940) The artificial production of seminal ejaculation. Anat. Rec. 76, 65.

Freund, M. (1958) Collection and liquefaction of guinea pig semen. Proc. Soc. exp. Biol. Med. 98, 538.

FREUND, M. (1962a) Initiation and development of semen production in the guinea pig. Fert. Steril. 13, 190.

FREUND, M. (1962b) Interrelationships among the characteristics of human semen and factors affecting semen-specimen quality. F. Reprod. Fert. 4, 143.

Freund, M. \& Borrelli, F. J. (1964a) Semen characteristics in the guinea pig. Proc. Vth Int. Congr. Animal Reprod. Plenary papers, 452.

Freund, M. \& Borrelli, F. J. (1964b) The effects of X-irradiation on male fertility in the guinea pig. Effect of 75, 150, and 300 roentgens of whole-body X-irradiation on semen production. Radiat. Res. 22, 404.

FreUnd, M. \& Borrelli, F. J. (1965) The effects of X-irradiation on male fertility in the guinea pig. Semen production after X-irradiation of the testis, of the body, or of the head. Radiat. Res. 24, 67.

Freund, M., Mixner, J. P. \& Mather, R. E. (1957) Bovine semen metabolism. II. Influence of sperm concentration and initial fructose level on fructolytic activity. F. Dairy Sci.40, 1308.

Freund, M. \& MuRphree, R. L. (1960) Effect of whole-body X-irradiation on the characteristics and metabolism of bull semen during the early post-irradiation period. J. Dairy Sci. 43, 1130.

Laurence, K. A. \& Carpuk, O. (1963) The counting and sizing of guinea pig spermatozoa. Fert. Steril. 14, 451 .

Moore, C. R. \& Gallagher, T. F. (1930) Seminal vesicle and prostate function as a testis-hormone indicator; the electric ejaculation test. Am. F. Anat. 45, 39.

OrIol-Bosch, A. \& PARAdA, J. (1960) Fructose im ejaculat. Endokrinologie, 39, 74.

SAYLes, E. D. (1939) Postnatal development of reproductive system in male guinea pigs and its relation to testis hormone secretion. Physiol. Zool. 12, 256. 
ScotT, J. V. \& Dzruk, P. J. (1959) Evaluation of the electroejaculation techniques and the spermatozoa thus obtained from rats, mice, and guinea pigs. Anat. Rec. 133, 655.

Semans, J. H. \& Langworthy, O. R. (1938) Observations on the neurophysiology of sexual function in the male cat. F. Urol. 40, 836 .

Umbreit, W. W., Burris, R. H. \& Staufper, J. F. (1964) Manometric techniques. Burgess, Minneapolis, Minn. 